\title{
Morphological and ultrastructural redescription of Chloromyxum leydigi Mingazzini, 1890 (Myxozoa: Myxosporea), type species of the genus, infecting the gall bladder of the marine cartilaginous fish Torpedo marmorata Risso (Chondrichthyes: Torpedinidae), from the Portuguese Atlantic coast
}

\author{
Sónia Rocha ${ }^{1,2}$, Graça Casal ${ }^{1,3}$, Saleh Al-Quraishy ${ }^{4}$ and Carlos Azevedo ${ }^{1,2,4}$ \\ ${ }^{1}$ Laboratory of Pathology, Interdisciplinary Centre of Marine and Environmental Research, University of Porto, Porto, Portugal; \\ ${ }^{2}$ Laboratory of Cell Biology, Institute of Biomedical Sciences, University of Porto, Porto, Portugal; \\ ${ }^{3}$ Department of Sciences, High Institute of Health Sciences - North, Gandra, Portugal; \\ ${ }^{4}$ Zoology Department, College of Sciences, King Saud University, Riyhad, Saudi Arabia
}

\begin{abstract}
Chloromyxum leydigi Mingazzini, 1890, the type species of Chloromyxum Mingazzini, 1890, is redescribed based on material found in the gall bladder of the cartilaginous fish Torpedo marmorata Risso collected from the Portuguese Atlantic coast and its sporogonic development is described. Plasmodia and mature spores were floating free in the bile. Plasmodia are polysporic and highly polymorphic in shape and organization. Mature spores are spherical to subspherical with a pointed anterior end, measuring $12.3 \pm 0.5 \mu \mathrm{m}$ in length and $9.0 \pm 0.5 \mu \mathrm{m}$ in width. The spore wall is composed of two asymmetric shell valves, each bearing 4-5 elevated surface ridges. A bundle of 40-50 tapering caudal filaments extends from the basal portion of the shell valves. Four pyriform equal-sized polar capsules, measuring about $5.3 \times 3.2 \mu \mathrm{m}$, are observed at the same level in the anterior pole of the spores, each containing a polar filament coiled in 8-9 (rarely 10) turns. Spore morphology, tissue tropism, host species and sequences of the SSU rRNA gene supported species identification. Since its discovery, this species has been dubiously reported from several cartilaginous hosts, namely due to the poor description of its features.
\end{abstract}

Keywords: coelozoic parasite, bile, stingray, sporogonic development, SSU rRNA

Amongst myxosporean genera, Chloromyxum Mingazzini, 1890 is the fourth largest, containing about 127 nominal species, most of which coelozoic in the urinary tract and gall bladder of both freshwater and marine fishes (Fiala and Dyková 2004, Lom and Dyková 2006, Azevedo et al. 2009, Casal et al. 2009, Gleeson and Adlard 2012, Rocha et al. 2013), and less frequently in non-fish hosts (Upton et al. 1995, Duncan et al. 2004, Jirků et al. 2006, 2011). Most reports of this genus refer to freshwater species infecting Osteichthyes, compared to the few reports that concern marine species (Lom and Dyková 2006). In the marine environment, Chloromyxum species appear to infect mostly Chondrichthyes (Pinto 1928, Kuznetsova 1977, Gioia and Cordeiro 1996, Azevedo et al. 2009, Eiras et al. 2012, Gleeson and Adlard 2012, Rocha et al. 2013).

Morphological features displayed by the spores diverge between the freshwater and marine environment. Chloromyxum species infecting marine cartilaginous fish hosts commonly possess oval spores with an attenuated apex and a posterior bundle of filamentous appendages
(Pinto 1928, Kuznetsova 1977, Kovaleva 1988, Gioia and Cordeiro 1996, Azevedo et al. 2009, Gleeson and Adlard 2012, Rocha et al. 2013). Also, the genus is polyphyletic, with the type-species clustering with the other marine species to form a clade at the basis of the main freshwater clade (Kent et al. 2001, Azevedo et al. 2009, Gleeson and Adlard 2012, Rocha et al. 2013), where the freshwater species cluster.

For many years, reports of species were solely based on light microscopy (LM) observations and schematic line drawings (Pinto 1928, Jameson 1929, Kuznetsova 1977, Mitchell et al. 1980, Kovaleva 1988, Gioia and Cordeiro 1996), which led to insufficient and incomplete descriptions that in most cases ultimately became the reason of many taxonomic confusions (Lom and Dyková 1992, 1993, 2006).

It is also the case of Chloromyxum leydigi Mingazzini, 1890, the type species of Chloromyxum, which has been the object of many morphological reports that contributed to an unclear description of the species (Kudo 1919, Pinto

Address for correspondence: C. Azevedo, Laboratory of Cell Biology, Institute of Biomedical Sciences (ICBAS/UP), University of Porto, Rua Jorge Viterbo Ferreira nº 228, 4050-313 Porto, Portugal. Phone: +351 220428 241; Fax: +351 220428 090. E-mail: azevedoc@icbas.up.pt 
1928, Gioia and Cordeiro 1996). LM provides valuable information, but only transmission electron microscopy (TEM) allows the recognition of specific ultrastructural features and scanning electron microscopy (SEM) permits the observation of specific surface patterns and characters (Lom and Dyková 1993, 2006, Jirků et al. 2011, Rocha et al. 2012).

The present study provides the morphological and ultrastructural redescription of $C$. leydigi based on material collected from the gall bladder of the cartilaginous fish Torpedo marmorata Risso captured from the northwest Portuguese Atlantic coast.

\section{MATERIALS AND METHODS}

Eighteen specimens of the marine spotted torpedo, Torpedo marmorata (Chondrichthyes, Torpedinidae), were sampled between November 2010 and November 2012 from the Portuguese Northwest Atlantic coast $\left(41^{\circ} 25^{\prime} \mathrm{N}, 08^{\circ} 46^{\prime} \mathrm{W}\right)$ near the city of Póvoa do Varzim. Upon necropsy, several organs and tissues, including muscles, gills, liver, intestine and gall bladder, were analysed for the detection of myxosporean parasites. Preliminary microscopical observations revealed the gall bladder as the only infected organ. The bile of the parasitized fishes was collected and prepared for observation by LM, including differential interference contrast (DIC) optics, TEM, SEM and for DNA sequencing.

Transmission electron microscopy: Free spores and plasmodia isolated from the bile were fixed in $5 \%$ glutaraldehyde buffered in $0.2 \mathrm{M}$ sodium cacodylate ( $\mathrm{pH} 7.4$ ) for $24 \mathrm{~h}$ at $4{ }^{\circ} \mathrm{C}$, washed overnight in the same buffer, and then post-fixed in $2 \%$ osmium tetroxide with the same buffer for $3 \mathrm{~h}$. After dehydration in an ascending ethanol series ending in propylene oxide, the samples were embedded in EPON. Semi-thin sections were stained with methylene blue-Azure II. Ultrathin sections were double-contrasted with uranyl acetate and lead citrate, observed and photographed using a JEOL 100CXII TEM, operated at $60 \mathrm{kV}$.

Scanning electron microscopy: Free spores and plasmodia isolated from the bile were fixed in 5\% glutaraldehyde buffered in $0.2 \mathrm{M}$ sodium cacodylate ( $\mathrm{pH} 7.4$ ) for $20 \mathrm{~h}$ at $4{ }^{\circ} \mathrm{C}$, washed in the same buffer at the same temperature and post-fixed in $2 \%$ osmium tetroxide with the same buffer for $3 \mathrm{~h}$. The samples were then dehydrated in an ascending ethanol series, critical point dried, coated with a gold-palladium alloy $(60 \%)$ and observed and photographed with a JSM-6301F SEM, operated at $15 \mathrm{kV}$.

DNA isolation, amplification and sequencing: Free spores and plasmodia isolated from the bile were preserved in $80 \%$ ethanol at $4{ }^{\circ} \mathrm{C}$. Genomic DNA extraction was performed using a GenElute ${ }^{\mathrm{TM}}$ Mammalian Genomic DNA Miniprep Kit, following the manufacturer's instructions. The DNA was stored in $50 \mu$ of TE buffer at $-20^{\circ} \mathrm{C}$ until further use. The SSU rRNA gene was amplified using both universal primers and myxosporean-specific primers: the 5'-end with the primers $18 \mathrm{e}\left(5^{\prime}-\mathrm{CT}-\right.$ GGTTGATCCTGCCAGT-3') (Hillis and Dixon 1991) and ACT4r (5'-CAATCGTGGTCGGTGCTA-3') (specific for Chloromyxum species); the 3 '-end with the primers ACT4f (5'-TAGCACCGACCACGATTG-3') (specific for Chloromyxum species) and 18r (5'-CTACGGAAACCTTGTTACG-3') (Whipps et al. 2003); and the overlapping region with the primers Myxo-
specF (5'-TTCTGCCCTATCAACTTGTTG-3') (Fiala 2006) and R3 (5'-GATTTTGGTCTCGTTCGTTAC-3').

PCRs were performed in $50 \mu \mathrm{l}$ reactions using $10 \mathrm{pmol}$ of each primer, $10 \mathrm{nmol}$ of each dNTP, $2.5 \mathrm{mM} \mathrm{MgCl}_{2}, 5 \mu 110 \times$ Taq polymerase buffer, 1.5 units Taq DNA polymerase, and 3 $\mu l$ of genomic DNA. The reactions were run on a Hybaid PxE Thermocycler, with initial denaturation at $95^{\circ} \mathrm{C}$ for $3 \mathrm{~min}$, followed by 35 cycles of $94^{\circ} \mathrm{C}$ for $45 \mathrm{sec}, 53^{\circ} \mathrm{C}$ for $45 \mathrm{sec}$, and $72^{\circ} \mathrm{C}$ for $90 \mathrm{sec}$. The final elongation step was performed at $72{ }^{\circ} \mathrm{C}$ for $7 \mathrm{~min}$. Five- $\mu 1$ aliquots of the PCR products were electrophoresed through a $1 \%$ agarose $1 \times$ tris-acetate-EDTA buffer (TAE) gel stained with ethidium bromide. The PCR products from different regions of the SSU rRNA gene were sequenced directly. The sequencing reactions were performed using a BigDye Terminator v1.1 from the Applied Biosystems Kit, and were run on an ABI3700 DNA analyzer (Perkin-Elmer, Applied Biosystems).

Distance analysis: The amplified sequences were assembled and the resulting consensus DNA sequence of the SSU rRNA gene was $1852 \mathrm{bp}$. The alignment was performed with ClustalW in MEGA 5 software (Tamura et al. 2011), with an opening gap penalty of 10 and a gap extension of 4 for both paired and multiple alignments. The distance estimation, for all sequenced Chloromyxum spp. infecting cartilaginous fish, was carried out in MEGA 5, using the Kimura-2 parameters model distance matrix for transitions and transversions. The number of base differences per sequence was also estimated. In both analyses all ambiguous positions were removed for each sequence pair, resulting in a total of 1878 positions in the final dataset.

\section{RESULTS}

Chloromyxum leydigi Mingazzini, 1890

Figs. 1-35

Plasmodia: Plasmodia polysporic, highly polymorphic, spherical, oval or very irregular (Figs. 1, 2, 6-8). Dimensions vary greatly as a result of polymorphic nature of these structures. Cellular membrane highly irregular with peripheral projections (Figs. 1, 6, 7), or almost smooth (Figs. 2, 8, 9). LM, including DIC, and TEM recognized sequential sporogonic stages (Figs. 1-19).

Sporogonic development: During earliest stages of sporogony, plasmodia contain generative cells, lipidic globules and other reserve bodies; cell membrane profusely covered by microvilli (Figs. 6, 14), some of which anastomosed (Fig. 14). During later stages of sporogony, plasmodia containing immature spores present less microvilli (Fig. 7); plasmodia containing mature spores rounded in shape with no peripheral projections and poorly constituted cytoplasm (Figs. 8, 15). Sporoblasts recognized by valvogenic, capsulogenic and sporoplasmogenic cells (Fig. 7). Two valvogenic cells surrounding remaining sporogonic cells, adhering together along suture line. Four capsulogenic cells, each with capsular primordium, nucleus and some paracrystallin structures, possibly proteins, and enclosed within vesicles. Later stages of capsulogenesis with immature polar capsules with arranged polar filament and persistent nuclei (Fig. 16). Mature spores within plasmodia enclosed in vacuole-like struc- 

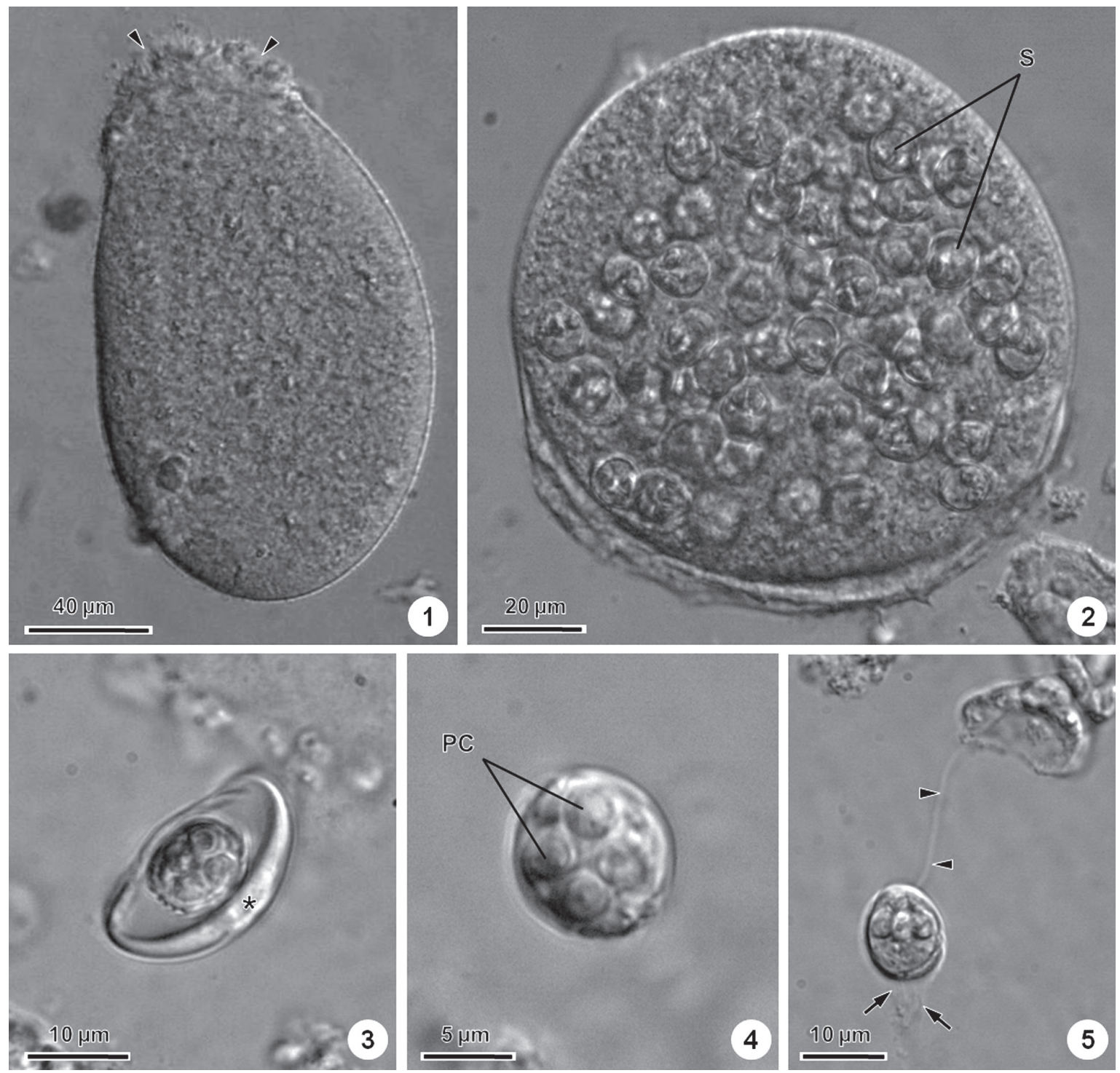

Figs. 1-5. Plasmodia and spores of Chloromyxum leydigi from the gall bladder of Torpedo marmorata; differential interference contrast. Fig. 1. Polymorphic plasmodium displaying highly irregular cellular membrane due to the presence of numerous peripheral projections (arrowheads). Fig. 2. Round plasmodium containing numerous mature spores (S). Fig. 3. Spore enclosed within a crescent-shaped structure $\left(^{*}\right)$. Fig. 4. Four polar capsules (PC) observed contained within each spore. Fig. 5. Bundle of caudal filaments (arrows) attached to the posterior pole; notice the extruded polar filament (arrowheads).

ture (Figs. 8, 15), surrounded by slightly denser cytoplasmatic material (Fig. 9). Mature spores released enclosed within crescent-shaped structure (Figs. 3, 10-12, 17, 18); caudal filaments tightly inserted (Figs. 11, 12, 19).

Spores (all measurements in mikrometres): Mature spores spherical to subspherical with pointed anterior end; $12.3 \pm 0.5$ long and $9.0 \pm 0.5$ wide $(\mathrm{n}=20)$ (Figs. 5 , 13). Spore wall composed of two asymmetric shell valves adhering together along S-shaped suture line (Figs. 20, 21, 23). Each valve with $4-5$ elevated surface ridges located in posterior half of spore, parallel to basal portion of suture line and coalescing towards apical pole (Figs. 28, 30). Bundle of 40-50 tapering caudal filaments attached to basal portion of shell valves (Figs. 20, 26, 30, 31); more specifically to basal ridge and suture line (Fig. 30). Caudal filaments $6.5 \pm 0.5$ long $(\mathrm{n}=5)$ and $c a 0.1$ in diameter $(n=10)$, constituted of same material composing shell valves: two continuous dense layers, one external and one internal, delimiting lighter middle area (Figs. 24, 25).

Four pyriform equal-sized polar capsules, 5.3 long and 3.2 wide $(\mathrm{n}=15)$, at same level in anterior pole (Figs. 20-22), each with isofilar polar filament, ca 35 long, coiled in 8-9 (rarely 10) turns along inner wall, obliquely arranged to longitudinal axis (Figs. 21, 22, 27). Extrusion pores located at anterior portion of shell valves, near suture line (Figs. 23, 29).

Sporoplasm irregular, displaying two nuclei randomly positioned in its matrix, numerous mitochondria, lipid 

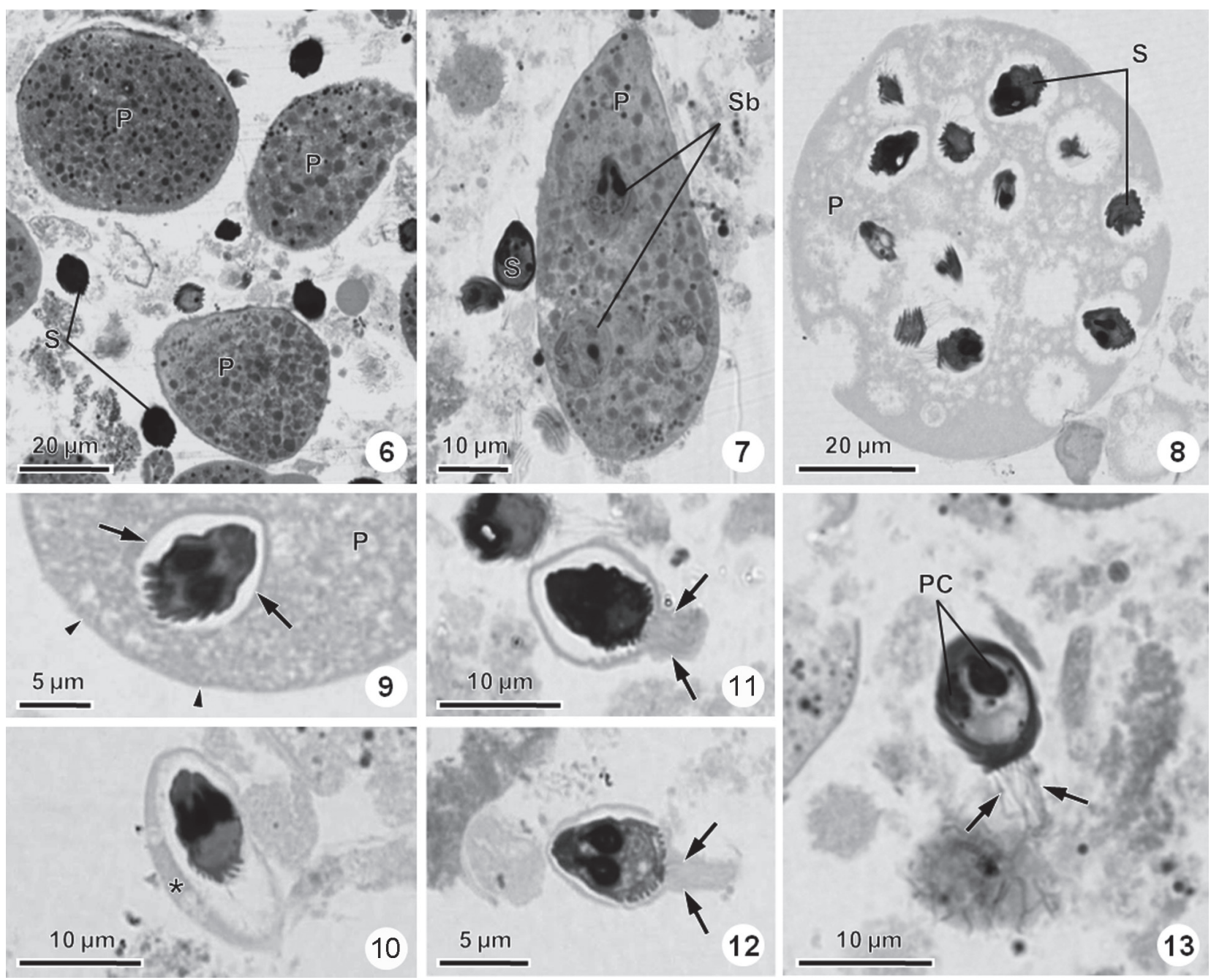

Figs. 6-13. Different stages of the sporogonic development of Chloromyxum leydigi from the gall bladder of Torpedo marmorata; light microscopy micrographs. Fig. 6. Several polymorphic plasmodia (P) corresponding to the earliest stages of sporogonic development, mature spores (S). Fig. 7. Plasmodium (P) displaying developing sporoblasts (Sb). Mature spore (S) located nearby. Fig. 8. Round-shaped plasmodium (P) containing mature spores (S). Fig. 9. Detail of the dense cytoplasmatic material (arrows) surrounding the spore within mature plasmodium $(\mathrm{P})$; the cellular membrane (arrowheads) lacks peripheral projections. Fig. 10. Spore enclosed within a crescent-shaped structure $\left({ }^{*}\right)$. Figs. 11, 12. Detailed aspect of the caudal filaments tightly inserted into the crescentshaped structure (arrows). Fig. 13. Mature spore presenting two of the four polar capsules (PC), as well as the bundle of caudal filaments (arrows) attached to the posterior pole.

globules, small vesicles and some sporoplasmosomes. Features of plasmodia, sporogonic development and mature spores illustrated in schematic drawings (Figs. 40-43).

Sequence analysis: Pairwise comparisons among the SSU rDNA sequences revealed significant similarity between Chloromyxum spp. infecting cartilaginous fishes, with the sequence obtained in this study presenting low genetic distance (0.003), corresponding to 5 nucleotide base differences when compared to C. leydigi (sequence Accession No. AY604199) from Torpedo marmorata (Table 1).

Type host: The spotted torpedo, Torpedo marmorata Risso (Chondrichthyes, Torpedinidae).

Other host: The Portuguese dogfish Centroscymnus coelolepis Barbosa du Bocage et de Brito Capelo (Chondrichthyes, Somniosidae).
Type locality: The Mediterranean Sea.

Other localities: European coast of the North Atlantic.

Site of infection: Plasmodia and spores observed in the bile.

Prevalence of infection: 61\% (11 infected in 18 examined fishes).

Deposition of materia 1: One glass slide with a semithin section displaying mature spores of this parasite is deposited in the Type Slide Collection of the Laboratory of Pathology, at the Interdisciplinary Centre of Marine and Environmental Research, University of Porto, Porto, Portugal, under acquisition 2013.1.

Remarks. Analysed stingrays were without macroscopic signs of infection, but necropsy revealed some specimens with hypertrophic gall bladders containing 

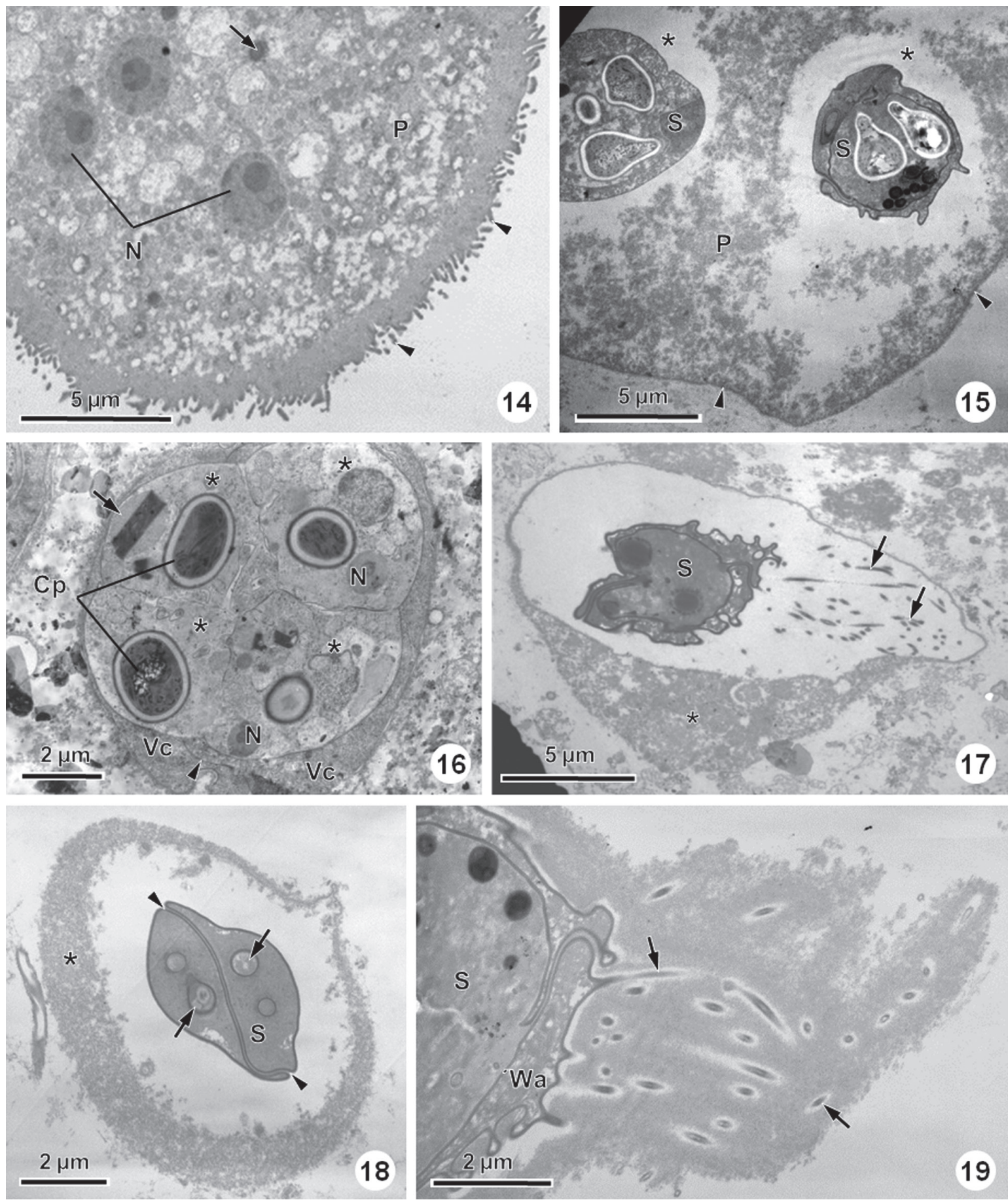

Figs. 14-19. Transmission electron micrographs of Chloromyxum leydigi from the gall bladder of Torpedo marmorata; different stages of sporogonic development. Fig. 14. Plasmodium (P) containing several vegetative nuclei (N) and lipidic globules (arrow), displaying a cellular membrane completely covered with microvilli (arrowheads). Fig. 15. Plasmodium (P) with two mature spores (S) located within vacuole-like structures $\left({ }^{*}\right)$. The cellular membrane (arrowheads) lacks peripheral projections. Fig. 16. Sporoblast showing two valvogenic cells $(\mathrm{Vc})$ adhering together along the suture line (arrowhead) and surrounding four capsulogenic cells $\left.{ }^{*}\right)$, each containing a developing capsular primordium $(\mathrm{Cp})$; nuclei $(\mathrm{N})$ of the capsulogenic cells remain until capsulogenesis is completed. Notice the presence of paracrystalline structures enclosed within vesicles (arrow). Fig. 17. Oblique section of a spore (S) enclosed within a crescent-shaped structure $\left(^{*}\right)$ and possessing caudal filaments (arrows) extending along the posterior pole. Fig. 18. Transverse section of the anterior pole of the crescent-shaped structure $\left(^{*}\right)$ allowing the recognition of four extrusion pores (arrows) located at the anterior pole of the spore (S), close to the suture line (arrowheads). Fig. 19. Detailed of a spore (S) showing caudal filaments (arrows) that project from the posterior portion of the shell valves (Wa), tightly inserted into the material forming the crescent-shaped structure. 
Table 1. Comparison of small subunit ribosomal DNA sequences of Chloromyxum spp. that infect cartilaginous fish; nucleotide difference (top diagonal) and pairwise distance (bottom diagonal) obtained by Kimura-two parameter analysis.

\begin{tabular}{llcccccccccccc}
\hline & Chloromyxum species & $(1)$ & $(2)$ & $(3)$ & $(4)$ & $(5)$ & $(6)$ & $(7)$ & $(8)$ & (9) & (10) & (11) & $(12)$ \\
\hline (1) & C. leydigi (present study) & - & 5 & 16 & 30 & 48 & 37 & 36 & 40 & 38 & 73 & 125 & 104 \\
(2) & C. leydigi (AY604199) & 0.003 & - & 17 & 31 & 45 & 38 & 37 & 41 & 39 & 72 & 124 & 105 \\
(3) Chloromyxum sp. (JN130384) & 0.012 & 0.012 & - & 23 & 20 & 39 & 32 & 42 & 35 & 46 & 68 & 101 \\
(4) & C. mingazzinii (JN130379) & 0.022 & 0.023 & 0.017 & - & 32 & 40 & 22 & 42 & 50 & 43 & 69 & 107 \\
(5) C. leydigi (DQ377710) & 0.027 & 0.025 & 0.014 & 0.024 & - & 38 & 37 & 45 & 41 & 75 & 121 & 107 \\
(6) & C. squali (JN130381) & 0.027 & 0.028 & 0.029 & 0.030 & 0.028 & - & 46 & 54 & 55 & 42 & 70 & 102 \\
(7) C. lesteri (JN130377) & 0.027 & 0.027 & 0.024 & 0.016 & 0.028 & 0.034 & - & 39 & 53 & 43 & 73 & 102 \\
(8) & C. kuhlii (JN130375) & 0.029 & 0.030 & 0.031 & 0.032 & 0.033 & 0.040 & 0.029 & - & 65 & 58 & 77 & 107 \\
(9) C. hemiscyllii (JN130374) & 0.029 & 0.030 & 0.026 & 0.038 & 0.031 & 0.042 & 0.041 & 0.050 & - & 55 & 80 & 101 \\
(10) C. clavatum (JQ793641) & 0.041 & 0.040 & 0.034 & 0.032 & 0.042 & 0.031 & 0.032 & 0.043 & 0.042 & - & 130 & 101 \\
(11) C. riorajum (FJ624481) & 0.073 & 0.072 & 0.050 & 0.053 & 0.070 & 0.053 & 0.055 & 0.058 & 0.062 & 0.076 & - & 114 \\
(12) C. myliobati (JN130380) & 0.080 & 0.080 & 0.077 & 0.083 & 0.082 & 0.078 & 0.078 & 0.082 & 0.079 & 0.077 & 0.088 & - \\
\hline
\end{tabular}
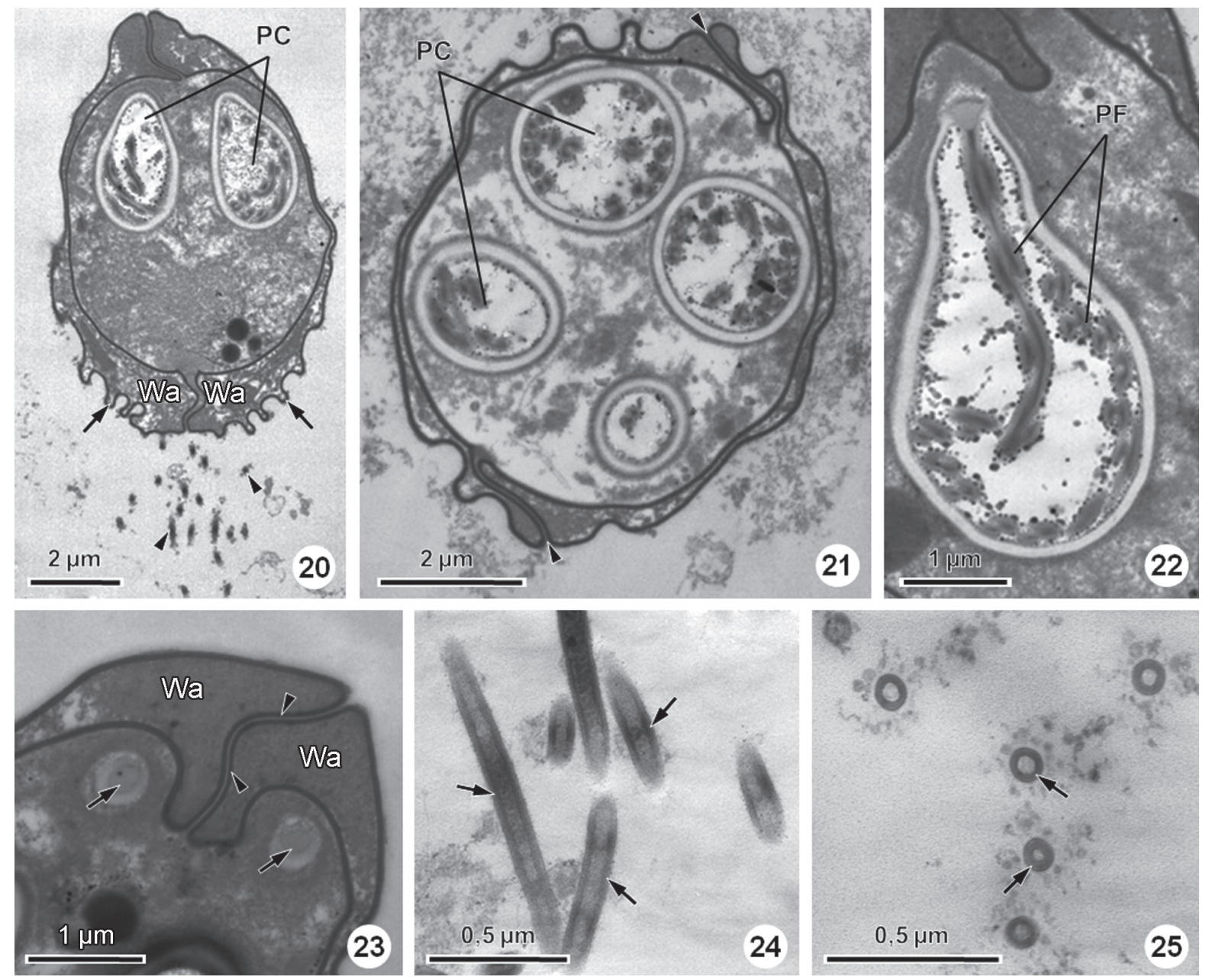

Figs. 20-25. Transmission electron micrographs of Chloromyxum leydigi from the gall bladder of Torpedo marmorata illustrating specific ultrastructural features of the spores. Fig. 20. Longitudinal section of a spore in lateral valvular view, showing two shell valves comprising its wall (Wa), two of the four polar capsules (PC) located at the anterior pole, and the bundle of caudal filaments (arrowheads) attached to the posterior pole. Notice the pattern formed by the surface ridges (arrows). Fig. 21. Transverse section of a spore allowing visualization of four polar capsules (PC) and two shell valves united along an S-shaped suture line (arrowheads). Fig. 22. Polar capsule in longitudinal section, showing polar filament (PF) coiled along the inner wall. Fig. 23. Detail of the anterior portion of shell valves (Wa), showing an S-shaped suture line (arrowheads) and extrusion pores (arrows). Fig. 24. Longitudinal section of caudal filaments (arrows). Fig. 25. Transverse section of caudal filaments (arrows). 

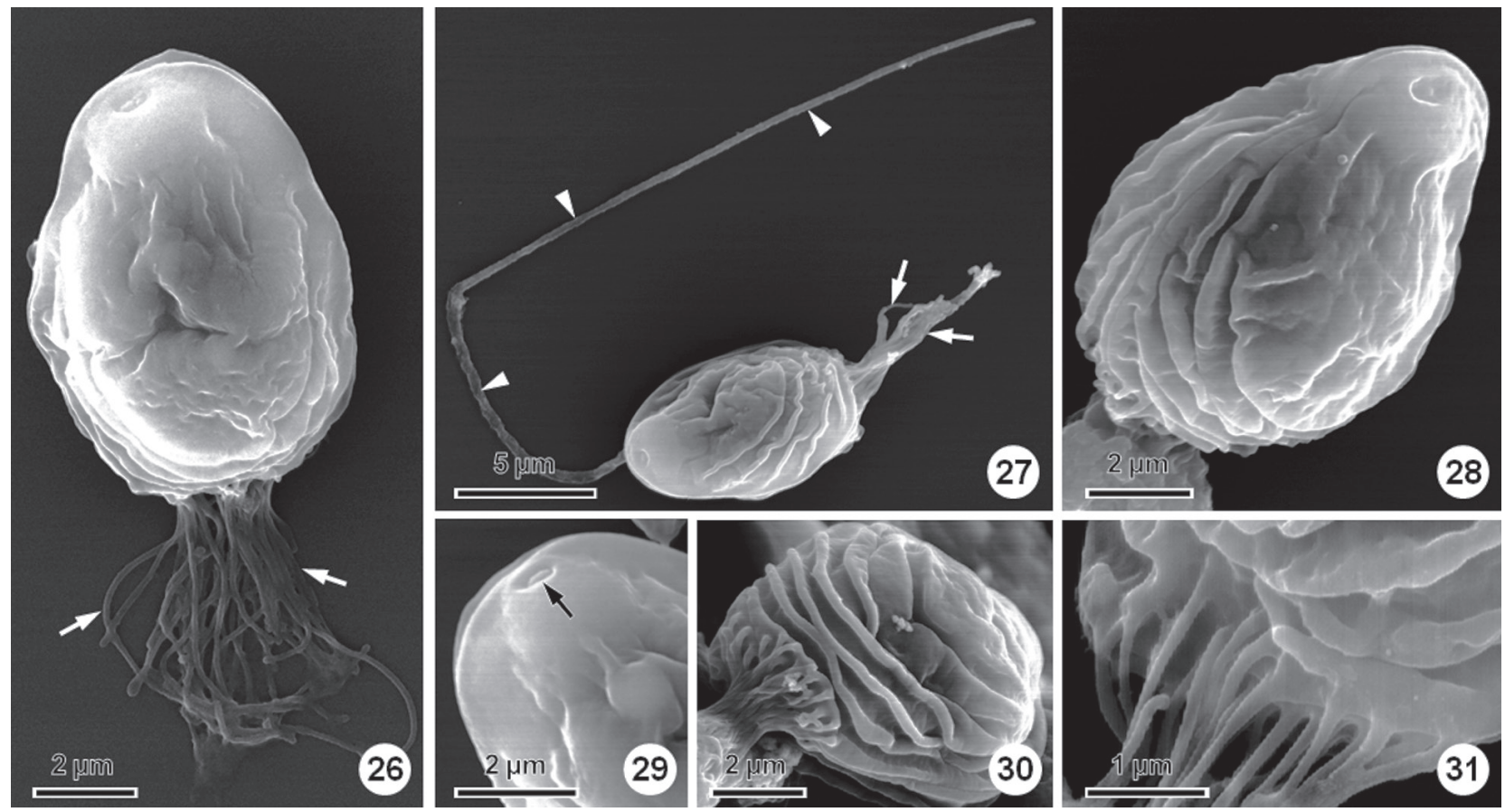

Figs. 26-31. Chloromyxum leydigi from the gall bladder of Torpedo marmorata; scanning electron micrographs. Fig. 26. Spore showing the bundle of caudal filaments (arrows) attached to its posterior pole. Fig. 27. Extruded polar filament (arrowheads) projecting from the extrusion pore located at the anterior portion of the shell valves; notice the bundle of caudal filaments (arrows) attached to the spore posterior pole. Fig. 28. Surface pattern formed by ridges positioned at the basal portion of each valve. Fig. 29. Detail of one of the four extrusion pores (arrow) located at the anterior portion of shell valves. Fig. 30. Posterior pole of a spore showing surface ridges and showing caudal filaments attached to the suture line and a more basal ridge of each valve. Fig. 31. Detail of caudal filaments attached to the spore through single insertions.

brownish coloured bile. Microscopic observations demonstrated parasitic infection in hypertrophied gall bladders, which displayed both plasmodia and spores floating in the bile.

\section{DISCUSSION}

The application of a range of microscopical procedures is required to describe myxosporean specific morphological characters fully and accurately. Since not all of these methodologies have been consistently performed, however, many species warrant redescription, leading, in some cases, to taxonomical revision (Lom and Dyková 1993, 2006). While several Chloromyxum species have been described from the gall bladder of marine cartilaginous fish, most of these reports lack the reliable and specific data which is necessary for taxonomic and comparative purposes (Cunha and Fonseca 1918, Pinto 1928, Jameson 1929, Kuznetsova 1977, Mitchell et al. 1980, Kovaleva 1988, Gioia and Cordeiro 1996). Indeed, with the increasingly widespread use of electron microscopy (both TEM and SEM) and DNA sequencing, the redescription of established species has become almost as frequent as the erection of new ones (Baska 1993, Lom and Dyková 1993, Ali 1998, Fiala and Dyková 2004, Holzer et al. 2006, Abdel-Baki 2007).
In the present study, the combined use of LM, TEM and SEM allowed the redescription of Chloromyxum leydigi, the type species of the genus. This species was originally described from the gall bladder of numerous species of sharks and skates of the genera Mustellus Fischer von Waldheim, Galeus Cuvier, Raja Linnaeus, Scyllium Cuvier, Squatina Duméril, Torpedo Houttuyn and Trygon Cuvier (Kudo 1919, Pinto 1928, Lom and Dyková 1992, 2006, Gioia and Cordeiro 1996). Although broad host specificity is a known feature of several myxosporean species (Hoffman et al. 1965, Diamant et al. 2006, Jirků et al. 2006), it is more likely that C. leydigi is in fact an assemblage of several species that infect the gall bladder of elasmobranchs (Jameson 1929, Kuznetsova 1977, Lom and Dyková 1992, 1993, 2006), as has been shown also for other Chloromyxum spp. (Bartošová and Fiala 2011). This would explain why, although many morphological features are consistent between the numerous different reports, others remain ambiguous (Kudo 1919, Lom and Dyková 1992).

According to the revision of myxosporean species made by Kudo (1919), all the previous reports of C. leydigi referred to the presence of polymorphic plasmodia with polysporic development and highly irregular cellular membranes, due to the presence of peripheral projections. Notwithstanding this broad similarity there are significant 

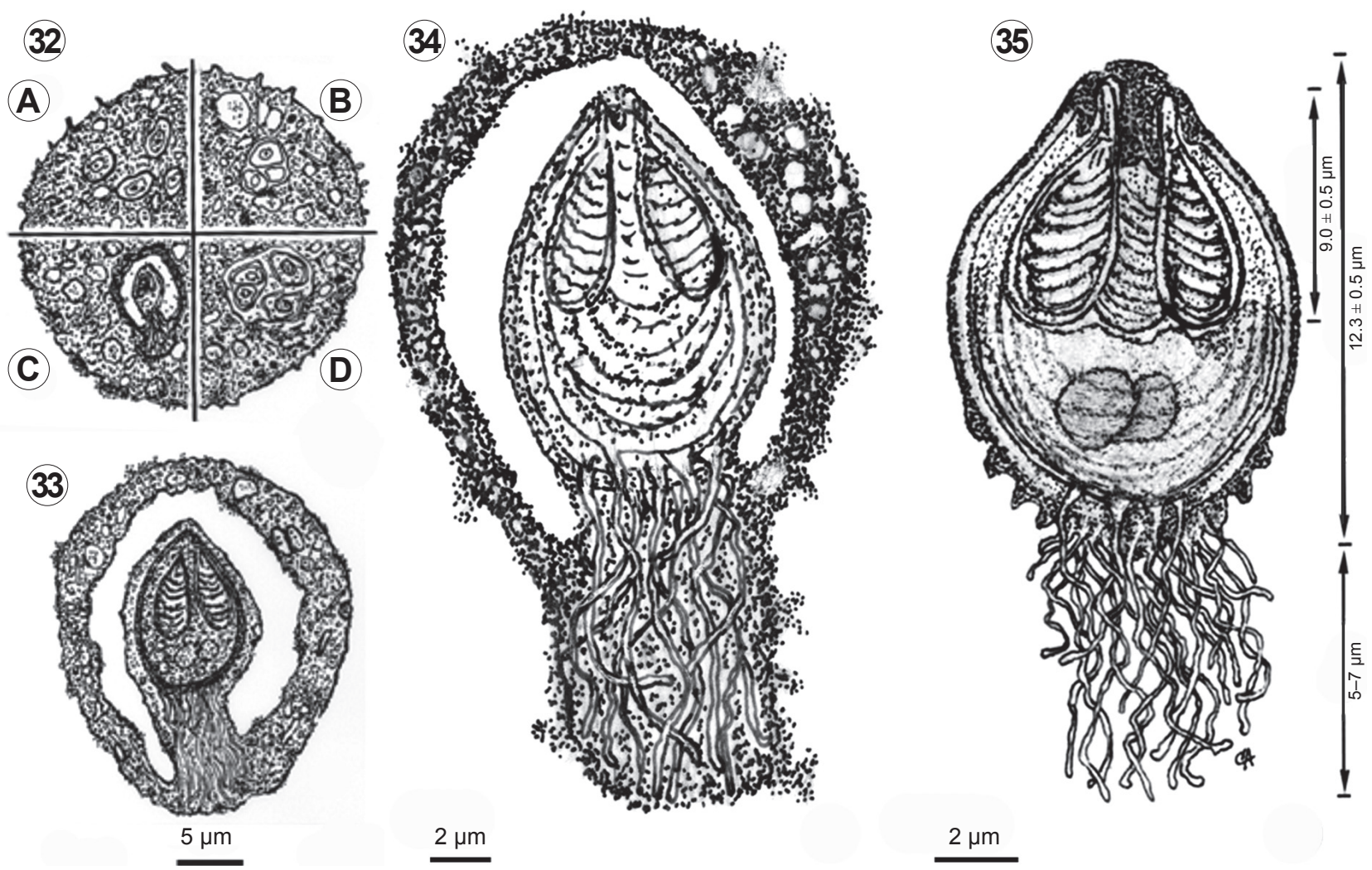

Figs. 32-35. Schematic drawings displaying the sequential sporogonic development of Chloromyxum leydigi from the gall bladder of Torpedo marmorata and including ultrastructural features of mature spores. Fig. 32. Plasmodium containing generative cells and numerous microvilli in the cellular membrane (A); plasmodium with proliferating generative cells and fewer microvilli in the cellular membrane (B); plasmodium containing developing sporoblasts (C); plasmodium starting to disintegrate, containing mature spores enclosed within vacuole-like structures (D). Fig. 33. Detail of the spore enclosed within a vacuole-like structure formed within the plasmodium. Fig. 34. Spore enclosed within a crescent-shaped structure, after disintegration of the plasmodium; notice caudal filaments tightly inserted into that structure. Fig. 35. Mature spore in longitudinal valvular view, detailing overall ultrastructural features.

disparities in the reports in respect to spore measurements, as well as a striking lack of conclusive comparative morphological characters (Kudo 1919, Pinto 1928, Lom and Dyková 1992, Gioia and Cordeiro 1996). In these circumstances, it is therefore reasonable to assume that $C$. leydigi constitutes nothing but a name attributed to every individual species found infecting the gall bladder of related hosts.

Finally, however, the species gained molecular identity through sequencing of the SSU rRNA gene of samples from the gall bladder of Torpedo marmorata captured from the Mediterranean Sea (Fiala and Dyková 2004), and later from the gall bladder of Centroscymnus coelolepis Barbosa du Bocage et de Brito Capelo captured from the North Atlantic (Fiala 2006).

These studies did not include morphological characterization, however, with only one scaled line drawing of C. leydigi from T. marmorata in Fiala and Dyková (2004) and one DIC micrograph of C. leydigi from Centroscymnus coelolepis in Fiala (2006).

In our study, the spores and polar capsules are smaller and the valves display fewer surface ridges than those considered by Lom and Dyková $(1992,2006)$ to represent $C$. leydigi sensu stricto. They concur, however, with the measurements and pattern of surface ridges given by Fiala and Dyková (2004) for C. leydigi infecting T. marmorata, albeit slightly smaller than the few spores depicted in the DIC micrograph provided by Fiala (2006) for $C$. leydigi from Centroscymnus coelolepis. Hence, the present study provides the first comprehensive data based on LM, TEM and SEM observations for the vegetative stages and spores of Chloromyxum leydigi.

Although often neglected in the description of myxosporean species, analysis of sporogonic development can provide valuable supplementary information to assist the distinction of individual species. During sporogony, plasmodia undergo many morphological and ultrastructural alterations, which vary according to tissue tropism. In coelozoic species, such as C. leydigi, plasmodial development is usually associated with variations of shape and dimension, as well as the occurrence of significant surface modifications through the differentiation of peripheral projections, probably related to nutritional intake, trophic functions and motility (Lom 1969, Lom et al. 1986, Sitjà- 
Bobadilla and Alvarez-Pellitero 1993, 2001, Lom and Dyková 1995, 1996, Canning et al. 1999, Rocha et al. 2011, Alama-Bermejo et al. 2012).

These kinds of alterations broadly concord with those observed here for C. leydigi. Early plasmodial stages were highly polymorphic and the cellular membrane contained peripheral projections. As the plasmodia evolved, however, the number of peripheral projections decreased, becoming completely absent so that the plasmodia were round-shaped and contained mature spores. The release of mature spores within crescent-shaped structures could be an additional protective measure for spores outside of the plasmodium. However, further microscopic analyses of these structures are necessary in order to assess the viability of this conjecture. The most plausible origin for the crescent-shaped structures is that they constitute the remnants of the vacuole-like structures surrounding the spores within the plasmodia. In turn, the vacuole-like structures possibly arose from the residual cytoplasm of the pansporoblasts and plasmodia, as was previously shown by Jirků et al. (2011) for the plasmodial and sporogonic development of Chloromyxum careni Mutschmann, 1990.

Mature spores were ultimately released from the crescent-shaped structures which were then observed floating empty in the bile. The occurrence of crescent-shaped structures enclosing spores, after the plasmodia disintegration, is unique among Chloromyxum species, thus representing a specific character for morphological species diagnosis.

Acknowledgments. This work was partially supported by Engineer António de Almeida Foundation (Portugal), Foundation for Science and Technology (Portugal), within the scope of the project DIRDAMyx, reference PTDC/MAR/116838/2010, and the project no. RGP-VPP-002 of King Saud University (Saudi Arabia). The authors wish to thank Miguel Cordeiro and fishermen from Póvoa do Varzim, for providing the specimens for analysis, as well as two reviewers for their comments.

\section{REFERENCES}

Abdel-Baki A.S. 2007: Chloromyxum alii sp. n. (Myxozoa: Myxosporea) infecting the gallbladder of African butter catfish Schilbe mystus (Linnaeus 1758) from the River Nile, Egypt: light and scanning electron microscopy. Acta Protozool. 46: 263-267.

Alama-Bermejo G., Bron J.E., Raga J.A., Holzer A.S. 2012: 3D morphology, ultrastructure and development of Ceratomyxa puntazzi stages: first insights into the mechanisms of motility and budding in the Myxozoa. PLoS ONE 7: e32679.

Ali M.A. 1998: Light and scanning electron microscopy of Chloromyxum vanasi sp. n. (Myxozoa: Myxosporea) infecting gallbladder of the Nile catfish Bagrus bayad (Forskål, 1775) (Teleosti: Bagridae). Acta Protozool. 37: 57-61.

Azevedo C., Casal G., Garcia P., Matos P., Teles-Grilo L., Matos E. 2009: Ultrastructural and phylogenetic data of Chloromyxum riorajum sp. nov. (Myxozoa), a parasite of the stingray Rioraja agassizii in southern Brazil. Dis. Aquat. Org. 85: 41-51.

Bartošová P., Fiala I. 2011: Molecular evidence for the existence of cryptic species assemblages of several myxosporeans (Myxozoa). Parasitol. Res. 108: 573-583.

BAsKa F. 1993. Light and electron microscopic studies on the development of Sphaerospora colomani Baska, 1990 and Chloromyxum inexpectatum Baska, 1990. Acta Vet. Hung. 41: 59-72.

Canning E.U., Curry A., Anderson C.L., Okamura B. 1999: Ultrastructure of Myxidium trachinorum sp. nov. from the gallbladder of the lesser weever fish Echiichthys vipera. Parasitol. Res. 85: 910-919.

Casal G., Garcia P., Matos P., Monteiro E., Matos E., AzeveDo C. 2009: Fine structure of Chloromyxum menticirrhi n. sp. (Myxozoa) infecting the urinary bladder of the marine teleost Menticirrhus americanus (Sciaenidae) in southern Brazil. Eur. J. Protistol. 45: 139-146.

Cunha A. M., Fonseca C. 1918: Sobre os mixosporídios dos peixes brasileiros. Bras. Med. 32: 393.

Diamant A., Ram S., Paperna I. 2006: Experimental transmission of Enteromyxum leei to freshwater fish. Dis. Aquat. Org. 72: $171-178$.
Duncan A.E., Garner M.M., Bartholomew J.L., Reichard T.A., Nordhausen R.W. 2004: Renal myxosporidiasis in Asian horned frog (Megophrys nasuta). J. Zoo Wildl. Med. 35: 381-386.

Eiras J.C., Lu Y.S., Gibson D.I., Fiala I., Saraiva A., Cruz C., Santos M.J. 2012: Synopsis of the species Chloromyxum Mingazinni, 1890 (Myxozoa: Myxosporea: Chloromyxidae). Syst. Parasitol. 83: 203-225.

Fiala I. 2006: The phylogeny of Myxosporea (Myxozoa) based on small subunit ribosomal RNA gene analysis. Int. J. Parasitol. 36: 1521-1534.

Fiala I., Dyková I. 2004: The phylogeny of marine and freshwater species of the genus Chloromyxum Mingazzini, 1890 (Myxosporea: Bivalvulida) based on small subunit ribosomal RNA gene sequences. Folia Parasitol. 51: 211-214.

Gioia I., Cordeiro N.S. 1996: Brazilian myxosporidians' checklist (Myxozoa). Acta Protozool. 35: 137-149.

Gleeson R.J., Adlard R.D. 2012: Phylogenetic relationships amongst Chloromyxum Mingazzini, 1890 (Myxozoa: Myxosporea), and the description of six novel species from Australian elasmobranchs. Parasitol. Int. 61: 267-274.

Hillis D.M., Dixon M.T. 1991: Ribosomal DNA: molecular evolution and phylogenetic inference. Q. Rev. Biol. 66: 411-453.

Hoffman G.L., Putz R.E., Dunbar C.E. 1965: Studies on Myxosoma cartilaginis n. sp. (Protozoa: Myxosporidea) of centrarchid fish and a synopsis of Myxosoma of North American freshwater fishes. J. Protozool. 12: 319-332.

Holzer A.S., Sommerville C., Wootten R. 2006: Molecular identity, phylogeny and life cycle of Chloromyxum schurovi Shul'man and Ieshko, 2003. Parasitol. Res. 99: 90-96.

JAmeson A.P. 1929: Myxosporidia from Californian fishes. J. Parasitol. 16: 59-68.

Jirků M., Bartošová P., Kodádková A., Mutschmann F. 2011: Another chloromyxid lineage: molecular phylogeny and redescription of Chloromyxum careni from the Asian horned frog Megophrys nasuta. J. Euk. Microbiol. 58: 50-59.

JirkŮ M., Bolek M.G., Whipps C.M., Janovy J., Kent M.L., Modrý D. 2006: A new species of Myxidium (Myxosporea: 
Myxidiidae), from the western chorus frog, Pseudacris triseriata triseriata, and Blanchard's cricket frog, Acris crepitans blanchardi (Hylidae), from eastern Nebraska: morphology, phylogeny, and critical comments on amphibian Myxidium taxonomy. J. Parasitol. 92: 611-619.

Kent M.L., Andree K.B., Bartholomew J.L., El-Matbouli M., Desser S.S., Devlin R.A., Feist S.W., Hedrick R.P., Hoffmann R.W., Khattra J., Hallett S.L., Lester R.J.G., Longshaw M., Palenzuela O., Siddall M.E., Xiao C. 2001: Recent advances in our knowledge of the Myxozoa. J. Euk. Microbiol. 48: 395-413.

Kovaleva A.A. 1988: [Myxosporidia of the genus Chloromyxum (Cnidospora, Myxosporea) of cartilaginous fish from the Atlantic coast of Africa]. Parazitologiya 22: 384-388. (In Russian.)

Kudo R.R. 1919: Studies on Myxosporidia. A synopsis on genera and species of Myxosporidia. Ill. Biol. Monogr. 5: 1-265.

Kuznetsova I.G. 1977: [Myxosporidians of Chondrostei from the Patagonian shelf.] Parazitologiya 11: 74-77. (In Russian.)

Lom J. 1969: Notes on the ultrastructure and sporoblast development in fish parasitizing myxosporidian of the genus Sphaeromyxa. Z. Zellforsch. 97: 416-437.

Lom J., Dyková I. 1992: Protozoan Parasites of Fishes. Developments in Aquaculture and Fisheries Science. Vol. 26. Elsevier, Amsterdam, $315 \mathrm{pp}$.

Lom J., Dyková I. 1993: Scanning electron microscopic revision of common species of the genus Chloromyxum (Myxozoa: Myxosporea) infecting European freshwater fishes. Folia Parasitol. 40: 161-174.

Lом J., Dүкоví I. 1995: New species of the genera Zschokkella and Ortholinea (Myxozoa) from the Southeast Asian teleost fish, Tetraodon fluviatilis. Folia Parasitol. 42: 161-168.

Loм J., DyкоvÁ I. 1996: Notes on the ultrastructure of two myxoporean (Myxozoa) species, Zschokkella pleomorpha and Ortholinea fluviatilis. Folia Parasitol. 43: 189-202.

Loм J., Dyкоvé I. 2006: Myxozoan genera: definition and notes on taxonomy, life-cycle terminology and pathogenic species. Folia Parasitol. 43: 1-36.

Lom J., Molnár K., Dyková I. 1986: Hoferellus gilsoni (Debaisieux, 1925) comb. n. (Myxozoa, Myxosporea): redescription and mode of attachment to the epithelium of the urinary bladder of its host, the European eel. Protistology 4: 405-413.

Received 10 April 2013
Mitchell L.G., Listebarger J.K., Bailey W.C. 1980: Epizzotiology and histopathology of Chloromyxum trijugum (Myxospora: Myxosporida) in centrarchid fishes from Iowa. J. Wildl. Dis. 16: 233-236.

Pinto C. 1928: Mixosporídeos e outros protozoários intestinais de peixes observados na América do Sul. Arch. Inst. Biol. São Paulo 1: 101-126.

Rocha S., Casal G., Al-Quraishy S., Azevedo C. 2013: Morphological and molecular characterization of a new myxozoan species (Myxosporea) infecting the gall bladder of Raja clavata (Chondrichthyes), from the Portuguese Atlantic coast. J. Parasitol. 99: 307-317.

Rocha S., Casal G., Matos P., Matos E., Dkhil M., AzeveDo C. 2011: Description of Triangulamyxa psittaca sp. nov. (Myxozoa: Myxosporea), a new parasite in the urinary bladder of Colomesus psittacus (Teleostei) from the Amazon River, with emphasis on the ultrastructure of plasmodial stages. Acta Protozool. 50: 327-338.

Sitjà-Bobadilla A., Alvarez-Pellitero P. 1993: Zschokkella mugilis n. sp. (Myxoporea: Bivalvulida) from mullets (Teleostei: Mugilidae) of Mediterranean waters: light and electron microscopic description. J. Euk. Microbiol. 40: 755-764.

SitjÀ-Bobadilla A., Alvarez-Pellitero P. 2001: Leptotheca sparidarum n. sp. (Myxosporea: Bivalvulida), a parasite from cultured common dentex (Dentex dentex L.) and gilthead sea bream (Sparus aurata L.) (Teleostei: Sparidae). J. Euk. Microbiol. 48: 627-639.

Tamura K., Dudley J., Nei M., Kumar S. 2011: MEGA5: Molecular evolutionary genetics analysis using maximum likelihood, evolutionary distance, and maximum parsimony methods. Mol. Biol. Evol. 28: 2731-2739.

Upton S.J., McAllister C.T., Trauth S.E. 1995: A new species of Chloromyxum (Myxozoa, Chloromyxidae) from the gall bladder of Eurycea spp. (Caudata, Plethodontidae) in North America. J. Wildl. Dis. 31: 394-396.

Whipps C.M., Adlard R.D., Bryant M.S., Lester R.J.G., FindLay V., Kent M.L. 2003: First report of three Kudoa species from Eastern Australia: Kudoa thyrsites from mahi mahi (Coryphaena hippurus), Kudoa amamiensis and Kudoa minithyrsites sp. nov. from sweeper (Pempheris ypsilychnus). J. Euk. Microbiol. 50: 215-219.

Accepted 6 June 2013 